Z. Klin. Chem. Klin. Biochem.

12. Jg. 1974, S. 444-448

\title{
An Improved Coupled Test Procedure for Glutathione Peroxidase (EC 1.11.1.9.) in Blood
}

\author{
By W. A. Günzler, H. Kremers and L. Flohé
}

Institut für Physiologische Chemie und Biochemie (Direktor: Prof. Dr. Dr. G. Weitzel) der Universität Tübingen

(Eingegangen am 12. Juni 1974)

\begin{abstract}
An optimized coupled test system for glutathione peroxidase in red blood cells is presented. In the improved assay, tert. butyl hydroperoxide was employed as an acceptor substrate at twenty times $\mathrm{K}_{\mathrm{m}}$ (app) concentration. By aid of a batching procedure for instant separation of hemoglobin from glutathione peroxidase, it could be proved that cyanmethemoglobin in the modified procedure does not affect the spontaneous reaction rate. Further possible interference with the determination could be excluded. Glutathione peroxidase activities in red blood cells of normal adults were measured by the improved test method. A glutathione peroxidase activity in human plasma was observed.
\end{abstract}

Die gekoppelte Testmethode zur Bestimmung von Glutathionperoxidase in Erythrocyten wurde optimiert. İm verbesserten Ansatz

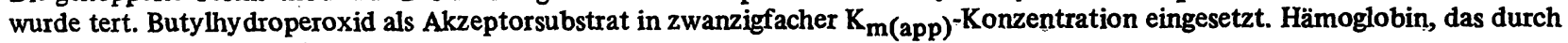
ein beschleunigtes Trennverfahren von Glutathionperoxidase gereinigt worden war, zeigte nach Transformation in Cyanmethämoglobin keinen Einfluß auf die Spontanreaktion. Einige weitere Störfaktoren konnten ausgeschlossen werden. Mit der verbesserten Testmethode wurde die Glutathionperoxidase-Aktivität in Erythrocyten von normälen Erwachsenen bestimmt . Eine GlutathionperoxidaseAktivität in Humanplasma wurde festgestellt.

Glutathione peroxidase has been widely accepted as an integral part of the cellular antioxidative system (1-4) and, recently, has turned out to be a selenoenzyme (5-9). Though determinations of glutathione peroxidase activity in human red blood cells have been carried out for several years (10-20), no assay for this enzyme activity has been developed, which can generally be accepted. At least two principally different test systems for glutathione peroxidase activity in hemolysate have been employed:

1. a fixed time assay, in which gluathione concentrations are measured at definite time intervals $(11,13,15$, 17), and

2. a coupled test system, in which glutathione reductase (EC 1.6.4.2.) is employed for regeneration of GSH. The decrease in NADPH concentration is continuously registrated photometrically $(10,12$, 14, 16-19).

Due to the different test systems and to the various assay conditions employed, the comparability of results from these investigations is rather limited (21). We, therefore, aimed at a test system, which would consider the kinetic properties of glutathione peroxidase $(22,23$, 24) and would cope with the difficulties arising from the determination of this enzyme activity in hemolysate $(10,25,17,21)$. In detail, our investigations were directed towards four problems:

1. The improvement of the assay conditions of the * coupled test system, which was initially suggested by Paglia \& Valentine (10).
2. The question, whether cyanmethemoglobin enhances the spontaneous reaction or not $(10,25,21)$.

3. The examination of various compounds, which could be supposed to interfere with the test.

4. A tentative application of the proposed procedure to hemolysate from washed erythrocytes and from capillary whole blood.

\section{Material and Methods \\ Glutathione reductase from yeast (crystalline suspension, $5 \mathrm{mg} / \mathrm{ml}$ ), NADPH (I grade), 6-phosphogluconate, ATP, 2,3-bisphosphoglycerate and NAD were purchased from Boẹ- ringer (Mannheim, Germany). Reduced glutathione (GSH) was obtained from Papierwerke Waldhof-Aschaffenburg AG (Mannheim, Germany), oxidized glutathione (GSSG) from Serva (Heidelberg, Germany) and tert. butyl hydroperoxide (80\%) from Merck-Schuchardt (München, Germany). Glutath- one peroxidase from bovine erythrocytes was isolated as outlined recently (24). Liquemin was a product of Hoffmann La Roche (Grenzach, Germany). Sephadex G 50 and DEAE Sephadex A 50 from Pharmacia (Uppsala, Sweden) were used. All other reagents were products "pro analy si" of.Merck AG (Darmstadt, Germany).}

\section{Preparation of hemolysate}

$5 \mathrm{ml}$ of blood were taken in tubes containing $0.3 \mathrm{ml}$ of $0.2 \mathrm{~mol} / \mathrm{l}$ EDTA (ethylenediamine tetraacetate, disodium salt). Plasma was withdrawn after centrifugation $(10 \mathrm{~min}, 2000 \mathrm{~g})$. Red blood cells were washed three times with saline before hemolysis in 25 volumes of bidistilled water. Stromata were removed by centrifugation $(20 \mathrm{~min}, 6000 \mathrm{~g})$. Capillary blood $(0.1 \mathrm{ml})$ was hemolyzed without pretreatment in $1 \mathrm{ml}$ of bidistilled water. The concentration of hemoglobin was determined in the hemolysate by the cyanmethemoglobin method (26) prior to dilution of the sample to a hemoglobin concentration of $3 \mathrm{~g} / 1$. 


\section{Preparation of cyanmethemoglobin}

Transformation of hemoglobin into cyanmethemoglobin was accomplished by a 1.2-fold excess of hexacyanoferrate[III] and a 12-fold excess of cyanide over heme concentration: 4 volumes of the adjusted hemolysate were treated with 1 volume of $0.9 \mathrm{mmol} / 1$ potassium hexacyanoferrate[III] solution ( $1 \mathrm{mmol} / 1$ in prim. potassium phosphate) and 1 volume of $9 \mathrm{mmol} / 1$ potassium cyanide solution $(7.5 \mathrm{mmol} / 1 \mathrm{in}$ prim. potassium phosphate).

\section{Photometric assay}

The test was performed at $37^{\circ} \mathrm{C}$ by aid of an "Eppendorf" photometer. The assay procedure is compiled in table 1.

Tab. 1. Composition of the photometric assay.

\begin{tabular}{lll}
\hline Reagent & $\begin{array}{l}\text { Volume } \\
(\mathrm{ml})\end{array}$ & $\begin{array}{l}\text { final } \\
\text { concentration }\end{array}$ \\
\hline $\begin{array}{l}\text { transformed hemolysate } \\
\left.\text { (spontaneous reaction: } \mathrm{H}_{2} \mathrm{O}\right)\end{array}$ & 0.5 & $1 \mathrm{~g} / 1$ methb-CN
\end{tabular}

glutathione reductase $(5 \mathrm{U} / \mathrm{ml})$

$0.2 \quad 1 \mathrm{U}^{+} / \mathrm{ml}$

dissolved in potassium phosphate

buffer $\mathrm{pH} 7.0(0.25 \mathrm{~mol} / \mathrm{l}$;

$2.5 \mathrm{mmol} / 1$ EDTA)

\section{GSH $(10 \mathrm{mmol} / \mathrm{l})$ in dist. water \\ $0.1 \quad 1 \mathrm{mmol} / 1$}

12 min preincubation at $37^{\circ} \mathrm{C}$
NADPH $(2.5 \mathrm{mmol} / \mathrm{l})$ in
$0.1 \quad 0.25 \mathrm{mmol} / \mathrm{l}$
$0.1 \% \mathrm{NaHCO}_{3}$

registration of hydroperoxide-independent NADPH consumption $(366 \mathrm{~nm})$

tert. butyl hydroperoxide

$(12 \mathrm{mmol} / \mathrm{l})$ in bidist. water, $37^{\circ} \mathrm{C}$

$0.1 \quad 1.2 \mathrm{mmol} / \mathrm{1}^{++}$

start of reaction

registration of overall NADPH consumption (366 nm)

+ assayed according to 1. c. (27)

tht determined iodometrically according to 1. c. (28)

When the interference of various compounds with the test was to be examined, the sample of transformed hemolysate was replaced by $0.5 \mathrm{ml}$ of purified bovine glutathione peroxidase incubated with the compound under study. $0.5 \mathrm{ml}$ of fresh human plasma was employed in the examination of plasma glutathione peroxidase activity.

The samples of transformed hemolysate were assayed within 24 hours. The solution of glutathione reductase was freshly prepared every day. GSH dissolved in water and NADPH dissolved in $0.1 \% \mathrm{NaHCO}_{3}$ were stored frozen for maximal 1 week; the stock solution of tert. butyl hydroperoxide in bidistilled water was stored at $4^{\circ} \mathrm{C}$ for maximal 2 weeks.

\section{Evaluation of recorded reaction rates}

Nonlinear NADPH consumption during the first 2 minutes of registration was disregarded. The reaction rates before addition of hydroperoxide were subtracted from the slopes of the overall reactions. The difference of these corrected slopes obtained from the hemolysate and the spontaneous reactions constitutes a measure of gluathione peroxidase activity in terms of absorption units per minute. The corresponding difference in concentrations of NADPH ( $\triangle$ [NADPH]) was calculated using an extinction coefficient at $366 \mathrm{~nm}$ of $3.3 \mathrm{~cm}^{2}$ / $\mu \mathrm{mol}$. The steady state concentration of GSH ([GSH] $]_{0}$ ) during the reaction was assumed to equal the final concentration of
GSH in the assay. Enzyme units for glutathione peroxidase were defined according to Flohé and Brand as:

$$
\begin{aligned}
& U_{37}=0.217 \times \Delta[\mathrm{NADPH}] /[\mathrm{GSH}]_{0} \times \min \\
& U_{37}=0.066 \times \Delta E_{366} / \mathrm{min}
\end{aligned}
$$

under the experimental conditions given above.

\section{Separation of hemoglobin and glutathione peroxidase}

Washed human erythrocytes were hemolyzed by distilled water, desalted by chromatography over Sephadex G 50 and fractionated on DEAE Sephadex A 50. The bulk of hemoglobin was washed from the column by $5 \mathrm{mmol} / 1$ potassium phosphate buffer (pH 7.0). A phosphate gradient up to $80 \mathrm{mmol} / \mathrm{l}$ was found to elute glutathione peroxidase at slightly higher phosphate concentrations than phosphogluconate dehydrogenase activity (EC 1.1.1.43.).

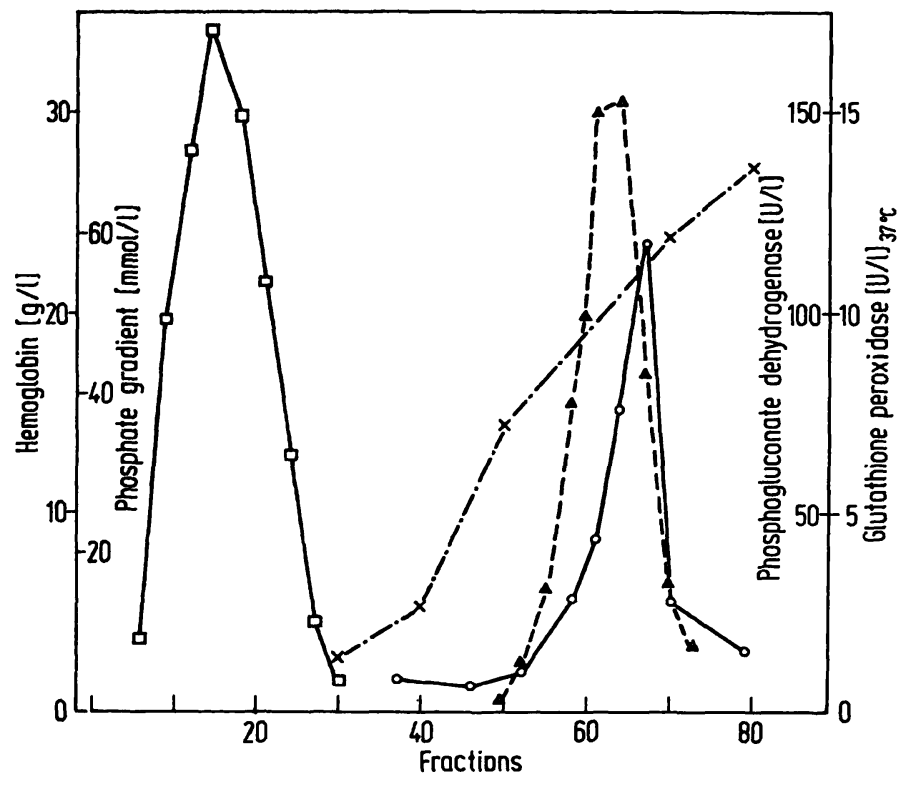

Fig. 1. Separation of glutathione peroxidase and hemoglobin of desalted human hemolysate by gradient elution from a DEAE Sephadex A 50 column.

$\leadsto$ Glutathione peroxidase activity measured at $37^{\circ} \mathrm{C}$

$\square$ Hemoglobin

ـ- Phosphogluconate dehydrogenase activity ${ }^{+}$

$x-\cdot-x$ Phosphate gradient ${ }^{++}$

+ assayed according to 1 . c. (29)

determined according to 1. c. (30)

This circumstance suggested a batching procedure, in which phosphogluconate dehydrogenase functioned as a marker activity: DEAE Sephadex equilibrated with $5 \mathrm{mmol} / 1$ potassium phosphate buffer $\mathrm{pH} 7.0$ was added to freshly prepared hemolysate until the phosphogluconate dehydrogenase activity had disappeared in the supernatant, thus indicating that all glutathione peroxidase had been adsorbed by the ion exchanging gel.

\section{Results and Discussion}

\section{Kinetic considerations concerning the assay}

Because no saturation of glutathione peroxidase by GSH can be achieved $(22,23,24)$, the enzymatic reaction rate follows at least pseudo first order kinetics. Whenever a spontaneous reaction of a comparable 
velocity competes with this enzymatic reaction, the application of the fixed time assay procedure must necessarily result in ambiguous values of enzyme activity $(25,17)$. The fixed time assay procedure, therefore, can only be advised at concentrations of glutathione peroxidase far beyond those found in human hemolysate (25).

The coupled test procedure, however, by rapidly regenerating GSH, can be managed at constant levels of donor substrate under pseudo zero order kinetics, when the enzyme is saturated with acceptor substrate (i. e. hydroperoxide). Complete saturation of glutathione peroxidase, however, proved not to be advisable, because the spontaneous reaction rates will be enhanced by increasing hydroperoxide concentrations. On the other hand, in the assay proposed by Paglia \& Valentine (10) hydroperoxide is employed at 3 times $\mathrm{K}_{\mathrm{m}}$ (app) concentration $(10,22,23)$, a concentration far too low to result in a constant enzymatic reaction rate. Only $75 \%$ maximum velocity of the enzymatic reaction rate can initially be expected by this procedure. In the assay presented, the acceptor substrate was employed at 20 times $\mathrm{K}_{\mathrm{m} \text { (app) }}$ concentration in order to approximate maximum velocity $\left(>90 \% \mathrm{~V}_{\max }\right)$. The slowing down of the spontaneous reaction caused by the consumption of acceptor substrate remained negligible. The overall reaction rates were reduced to their enzymatic entity by merely subtracting the spontaneous effects.

Tert. butyl hydroperoxide was used as an acceptor substrate in this assay (21). Since this hydroperoxide is not consumed by catalase, azide can be omitted from the improved assay. Tert. butyl hydroperoxide has been shown to exhibit maximum velocities equal to those obtained with $\mathrm{H}_{2} \mathrm{O}_{2}$ as an acceptor substrate of glutathione peroxidase (23). In order not to inhibit glutathione reductase, GSH was used at $1 \mathrm{mmol} / 1$ in the assay (25). From the corresponding apparent $K_{m}$ value a tert. butyl hydroperoxide concentration of $1.2 \mathrm{mmol} / 1$ is proposed in the improved assay procedure. A comparable saturation of glutathione peroxidase by $\mathrm{H}_{2} \mathrm{O}_{2}$ could be achieved at a molarity 10 times lower. However, since under equal saturation the consumption of either acceptor substrate procedes at equal rates, the percentage of decrease in acceptor substrate concentration will be 10 times higher with $\mathrm{H}_{2} \mathrm{O}_{2}$ than with tert. butyl hydroperoxide. A fast decrease in the reaction rate is thus observed under these conditions with $\mathrm{H}_{2} \mathrm{O}_{2}$ as substrate.

Due to the properties of the coupled test system, a sufficient excess of glutathione reductase activity has to be provided, in order to keep the concentration of GSH at a definite level. Though there is no indication of an interference with the test procedure proposed, the possibility of a decrease in readily available GSH by the formation of mixed disulfides with protein SH-groups must be kept in mind (31).
The kinetic properties of glutathione peroxidase imply that international units of enzyme activity do not make sense, unless they are related to the amount of GSH actually present in the assay. Units for this enzyme activity therefore should be defined as the quotient:

$$
0.434 \frac{\Delta[\mathrm{GSH}]}{\min X[\mathrm{GSH}]_{0}} \text {, where } \Delta[\mathrm{GSH}]_{1} \text { min represents }
$$

the GSH turnover as measured by NADPH consumption, and $[\mathrm{GSH}]_{0}$ equals the steady state concentration of GSH in the test sample. The factor 0.434 transforms the first order reaction rate constant, corresponding to the quotient, into decadic logarithms, in order to facilitate the comparison with enzyme units determined with a fixed time assay procedure and defined as $\Delta \log [\mathrm{GSH}] / \mathrm{min}(25)$.

As outlined above, one of the major difficulties in the evaluation of this enzyme activity results from the rapid spontaneous reaction of the substrates. Since the enzymatic reaction has an appreciably higher temperature coefficient than the nonenzymatic one (32), the interference of the latter reaction can be considerably reduced just by elevating the temperatur of the assay. This is the reason, why in this special case we like to recommend that the test be performed at $37^{\circ} \mathrm{C}$ instead of $25^{\circ} \mathrm{C}$.

\section{Lack of influence of cyanmethemoglobin on the test}

Paglia \& Valentine supposed an interference of methemoglobin reductase with the glutathione peroxidasedependent NADPH consumption in the coupled test and, therefore, suggested the transformation of methemoglobin into cyanmethemoglobin (10). Since several porphyrin proteins exhibit pseudoperoxidative activities $(25,31)$, the question arose whether cyanmethemoglobin would share this quality. Starting from hemolysate, which was freed from glutathione peroxidase by extensive chromatographic procedures, it was found that this activity was reduced to a large extent by ' complexing methemoglobin with an excess of cyanide $(25,21)$. However, the pseudoperoxidative activity could not be abolished completely in these preparations and it appeared to contribute to a considerable degree to the glutathione peroxidase activities measured in transformed hemolysate (21). Further investigations revealed that the extent of the interfering reaction could not be standardized, because the peroxidative activity obviously depended on the mode of hemoglobin preparation. An accelerated procedure for separating glutathione peroxidase from hemoglobin, in which phosphogluconate dehydrogenase was used as a marker activity, finally yielded cyanmethemoglobin samples lacking pseudoperoxidative activity. In contrast to our previous statements $(25,21)$ we therefore conclude that cyanmethomoglobin from fresh hemolysate will not contribute to the hydroperoxide-dependent NADPH consumption. Therefore, provided that fresh hemo- 
lysate is employed and hemoglobin is completely transformed into cyanmethemoglobin, merely buffer instead of cyanmethemoglobin solution can be used as a blank.

\section{Influence of several further compounds on the test}

Inhibition of glutathione peroxidase by several compounds, especially by anions, has been reported (32, $25,33,34)$. Therefore a number of compounds, which could be supposed to affect the test, were examined using purified glutathione peroxidase from bovine red blood cells.

Tab. 2. Influence of some compounds on the assay of purified bovine glutathione peroxidase activity.

\begin{tabular}{|c|c|c|}
\hline Compound & $\begin{array}{l}\text { final } \\
\text { concentration } \\
\text { in the assay }\end{array}$ & $\begin{array}{l}\text { effect } \\
\text { observed }\end{array}$ \\
\hline EDTA (disodium salt) & $\begin{array}{r}\leqslant 16 \mathrm{mmol} / 1 \\
66 \mathrm{mmol} / 1\end{array}$ & $\begin{array}{l}\text { no inhibition } \\
50 \% \text { inhibition }\end{array}$ \\
\hline Citrate (trisodium salt) & $\leqslant \begin{array}{r}2 \mathrm{mmol} / 1 \\
25 \mathrm{mmol} / 1\end{array}$ & $\begin{array}{l}\text { no inhibition } \\
50 \% \text { inhibition }\end{array}$ \\
\hline Liquemin & $\begin{array}{l}1 \text { USP-E./ml } \\
2 \text { USP-E./ml } \\
8 \text { USP-E./ml }\end{array}$ & $\begin{array}{l}35 \% \text { inhibition } \\
55 \% \text { inhibition } \\
100 \% \text { inhibition }\end{array}$ \\
\hline $\mathrm{CCl}_{4}$ & saturated buffer & no inhibition \\
\hline \multirow[t]{2}{*}{$\begin{array}{l}\mathrm{K}_{3}\left[\mathrm{Fe}(\mathrm{CN})_{6}\right] \\
\text { without bovine serum } \\
\text { albumin }\end{array}$} & $20 \mu \mathrm{mol} / 1$ & $\begin{array}{l}\text { after } 30 \text { min: } \\
20 \% \text { inhibition }\end{array}$ \\
\hline & & $\begin{array}{l}\text { after } 240 \mathrm{~min}: \\
50 \% \text { inhibition }\end{array}$ \\
\hline $\begin{array}{l}\text { with bovine serum albumin } \\
\text { ( } 1 \mathrm{~g} / 1 \text { assay) }\end{array}$ & & $\begin{array}{l}\text { up to } 90 \mathrm{~min}: \\
\text { no inhibition }\end{array}$ \\
\hline $\mathrm{KCN}$ & $2 \mathrm{mmol} / 1$ & no inhibition \\
\hline ATP & $1 \mathrm{mmol} / 1$ & no inhibition \\
\hline $\begin{array}{l}\text { 2,3-bisphosphoglycerate } \\
\text { (cyclohexylammonium salt) }\end{array}$ & $6 \mathrm{mmol} / 1$ & no inhibition \\
\hline
\end{tabular}

A strong inhibition of glutathione peroxidase activity was observed with Liquemin. Heparin therefore was abandoned as an anticoagulant in our procedure. EDTA was found to be less inhibitory compared with citrate and was preferred as a complexing reagent in whole blood.

Though, the addition of bovine serum albumin abolished the decrease in purified glutathione peroxidase activity caused by hexacyanoferrate[III], the excess of this reagent in the assay was limited to $20 \%$ over heme concentration. Cyanide did not affect the enzymatic reaction rate up to $2 \mathrm{mmol} / \mathrm{l}$ and could be employed at 12 times heme concentration.
ATP and 2,3-bisphosphoglycerate do not interfere with the glutathione peroxidase determination at the concentrations resulting from the hemolysate sample.

\section{Application of the test procedure}

The application of the test procedure described above to washed red blood cells from normal human adults yielded a mean glutathione peroxidase activity of $2.1 \mathrm{U}_{37} / \mathrm{g}$ of hemoglobin $(\mathrm{SD} \pm 28.6 \% ; n=35)$. The reproducibility of the improved test procedure is stressed by a SD-value of $\pm 3.8 \%$ for parallel determinations. The high standard deviation found in the blood samples, therefore, is attributable to biological variations.

In order to assay glutathione peroxidase in blood samples of minimal volume (e. g. in capillary blood), some further determinations were performed, in which the separation of red blood cells was omitted. The results from this simplified procedure comprise a glutathione peroxidative activity found in human plasma, which in preliminary investigations ranged at about $25 \mathrm{U}_{37} / \mathrm{l}$, i. e. a plasma activity of $5 \%$ of the ery throcy tic glutathione peroxidase activity per volume of whole blood. Though in these determinations tert. butyl hydroperoxide was used as a relatively specific acceptor substrate, the identity of the glutathione peroxidative activity in plasma with glutathione peroxidase remains to be established.

In conclusion the improved test system presented yields reliable results with unpurified hemolysate from washed ery throcytes, whole capillary blood or with plasma as well as with purified enzyme preparations. The employed concentrations of substrates guarantee a constant reaction velocity over several minutes. The use of tert. butyl hydroperoxide instead of $\mathrm{H}_{2} \mathrm{O}_{2}$ and the elevated temperature of the assay result in an appreciably increased difference between the spontaneous and enzymatic reaction rate. The definition of the activity unit takes account of the kinetic properties of the enzyme and allows an easy comparison of the results obtained with the coupled test system with those obtained with the different types of the fixed time assay. The proposed method requires only standard laboratory equipment and may be of great value in the investigation of genetic disorders $(12,13,18,20)$ and selenium deficiency $(5,8)$.

\section{Acknowledgements}

$H$. Kremers is supported by a fellowship from the Deutsche Forschungsgemeinschaft. Stimulating discussions with Dr. $A$. Wendel are gratefully acknowledged. 


\section{References}

1. Flohé, L. (1971), Klin. Wochenschr. 49, 669-683.

2. Smith, A. G., Harland, W. A. \& Brooks, C. J. W. (1973), Steroids Lipids Res. 4, 122-128.

3. Aebi, H. \& Suter, H. (1974), in Glutathione (Flohé, L., Benöhr, H. Ch., Sies, H., Waller, H. D. \& Wendel, A., eds.), 192-201, Georg Thieme Verlag, Stuttgart.

4. Flohé, L. \& Zimmermann, R. (1974), in Glutathione (Flohé, L., Benöhr, H. Ch., Sies, H., Waller, H. D. \& Wendel, A., eds.), 245-260, Georg Thieme Verlag, Stuttgart.

5. Rotruck, J. T., Pope, A. L., Ganther, H. E., Swanson, A. B., Hafeman, D. G. \& Hoekstra, W. G. (1973), Science 179, $588-590$.

6. Flohé, L., Günzler, W. A. \& Schock, H. H. (1973), FEBS Lett. 32, 132-134.

7. Hoekstra, W. G., Hafeman, D., Oh, S. H., Sunde, R. A. \& Ganther, H. E. (1973), Fed. Proc. Fed. Amer. Soc. Exp. Biol. 32, 885.

8. Noguchi, T., Cantor, A. H. \& Scott, M. L. (1973), J. Nutr. $103,1502-1511$.

9. Günzler, W. A. (1974), thesis, Tübingen.

10. Paglia, D. E. \& Valentine, W. N. (1967), J. Lab. Clin. Med. 70, 158-169.

11. Gross, R. T., Bracci, R., Rudolph, N., Schroeder, E. \& Kochen, J. A. (1967), Blood 29, 481-493.

12. Boivin, P., Galand, C., Hakim, J., Rogé, J. \& Guéroult, N. (1969), Enzymol. Biol. Clin. 10, 68-80.

13. Necheles, T. F., Boles, T. A. \& Allen, D. M. (1968), J. Pediatrics 72, 319-324.

14. Whaun, J. M. \& Oski, F. A. (1970), J. Pediatrics 76, 555560.

15. Vetrella, M., Barthelmai, W. \& Rietkötter, J. (1970), Klin. Wochenschr. 48, 85-88.

16. Butenandt, O. (1971), Z. Kinderheilk. 111, 149-161.

17. Emerson, P. M., Mason, D. Y. \& Cuthbert, J. E. (1972), Brit. J. Haematol. 22, 667-680.

18. Nishimura, Y., Chida, N., Hayashi, T. \& Arakawa, T. (1972), Tohoku J. Exp. Med. 108, 207-217.
19. Hopkins, J. \& Tudhope, G. R. (1973), Brit. J. Haematol. $25,563-577$.

20. Necheles, T. F. (1974), in Glutathione (Flohé, L., Benöhr, H. Ch., Sies, H., Waller, H. D. \& Wendel, A., eds.), 173-180, Georg Thieme Verlag, Stuttgart.

21. Günzler, W. A. (1974), in Glutathione (Flohé, L., Benöhr, H. Ch., Sies, H., Waller, H. D. \& Wendel, A., eds.), 180-184, Georg Thieme Verlag, Stuttgart.

22. Flohé, L., Loschen, G., Günzler, W. A. \& Eichele, E. (1972), Hoppe-Seyler's Z. Physiol. Chem. 353, 987-999.

23. Günzler, W. A., Vergin, H., Müller, I. \& Flohé, L. (1972), Hoppe-Seyler's Z. Physiol. Chem. 353, 1001-1004.

24. Flohé, L. \& Günzler, W. A. (1974), in Glutathione (Flohé, L., Benöhr, H. Ch., Sies, H., Waller, H. D. \& Wendel, A., eds.), 132-145, Georg Thieme Verlag, Stuttgart.

25. Flohé, L. \& Brand, I. (1970), this J. 8, 156-161.

26. Richterich, R. (1968), in Klinische Chemie, 333-335, Akad. Verlagsgesellschaft, Frankfurt/Main.

27. Horn, H. D. (1962), in Methoden der Enzymatischen Analyse (Bergmeyer, H. U., ed.), 875-877, Verlag.Chemie, Weinheim.

28. Kolthoff, I. M. \& Medalia, A. I. (1949), J. Amer. Chem. Soc. 56, 658-666.

29. King, J. (1970), in Methoden der Enzymatischen Analyse (Bergmeyer, H. U., ed.), 595-598, Verlag Chemie, Weinheim.

30. Fiske, C. H. \& Subbarow, Y. (1925), J. Biol. Chem. 66, 375.

31. Olinescu, R. \& Nita, S. (1973), Rev. Roum. Biochem. 10, 119-129.

32. Schneider, F. \& Flohé, L. (1967), Hoppe-Seyler's Z. Physiol. Chem. 348, 540-552.

33. Little, C., Olinescu, R. M., Reid, K. G. \& O'Brien, P. J. (1970), J. Biol. Chem. 245, 3632-3636.

34. Little, C., Olinescu, R. M. \& O'Brien, P. J. (1970), Biochem. Biophys. Res. Commun. 41, 287-293.
Dr. W. A. Günzler

Dr. H. Kremers

D 74 Tübingen

Hoppe-Seyler-Straße 1

Priv.-Doz. Dr. L. Flohé Chemie Grünenthal $\mathrm{GmbH}$ D 519 Stolberg/Rhld. 